\title{
The Impact of Interaction Between Enterprise Resource Planning System and Management Control System on Firm Performance in The Turkish Manufacturing Sector
}

\author{
Melek Eker $^{\mathrm{a}} \quad$ Semih Eker ${ }^{\mathrm{b}}$
}

\begin{abstract}
The developments of information and communication technology affect the way of data collecting and storing for firms. This has also lead to improving information processing process and management control processes. The purpose of this study is to show whether the interaction between the enterprise resource planning system and the management control system leads to an improvement in firm performance. The model of Kallunki, Laitinen, and Silvola (2011) is used to understand and analyze the relationship in Turkey. To test the relationship empirically, data is gathered from 125 manufacturing firms of the top 500 in Turkey in 2015. The results support the hypothesis that high interaction between enterprise resource planning system and management control system is associated with high financial and nonfinancial performance.
\end{abstract}

Keywords: ERP, Formal Control, Informal Control, Financial performance, Non-Financial Performance

JEL Classification: M41, M42, 033

\section{Introduction}

The relationship between enterprise resource planning system (ERP) and management control system (MCS) has been studied with great interest since the last ten years. The question looking for an answer is that how firms will use ERP to support its MCS. When the relevant literature is examined, it can be said that the effect of ERP-MCS interaction on firm performance is relatively less investigated than the relationship between ERP and MCS.

ERP creates an important informative technological infrastructure for cost and management control systems of firms (Beaubien, 2013: 49) It is important to collect, store, report and communicate detailed and real-time information on workplace behaviors to manage and control. So, It is impossible to talk about the impact on MCS and firm performance regardless of the ERP that provides the information infrastructure that is the meeting point of many units (Dechow, Granlund and Mouritsen, 2007: 625).

Until the 1990s, each unit in the enterprises was using its own information system independently of other units. With the development of ERP system, it has become possible to use the management control systems in an interactive manner and to develop them by establishing a database that can be accessed

\footnotetext{
${ }^{a}$ Assoc. Prof., PhD., Uludag University, Faculty of Economics and Administrative Sciences, Department of Business Administration, Bursa, Turkiye, melekeker@uludag.edu.tr (ORCID ID: 0000-0002-0353-4855)

${ }^{b}$ Lecturer, PhD., Uludag University, Faculty of Economics and Administrative Sciences, Department of Political Science and Public Administration, Bursa, Turkiye, semiheker@uludag.edu.tr (ORCID ID: 0000-0002-0017-8437)
} 
remotely and instantly. In this manner, ERP has become an important player in realizing management control objectives as it integrates business processes and provides all staff with real-time data distribution.

So the focus of this study is to empirically demonstrate the effect of the interaction of ERP and MCS on firm performance in Turkey. To do this, data from 125 companies in 500 large enterprises were collected and analyzed.

\section{Literature Review}

Few studies have been done to investigate the interaction between ERP and management control systems on firm performance. According to the findings, the effect of the interaction of ERP and MCS on firm performance is positive.

Kallunki, Laitinen and Silvola (2011: 20) examined the role of formal and informal MCS as a mechanism which mediates the effect of ERP systems on firm performance using the survey data of 70 Finnish business. The findings show that formal types MCS act as intervening variables mediating the positive lagged effect between enterprise systems adoption and non-financial performance. Informal types MCS, however, do not show similar mediating effects. Maroofi, Kiani, and Nazaripour (2012: 51) also found the same results by using the field study of 210 industrial organizations in Iran.

Maiga, Nilson and Jacobs (2013: 1) investigated the interaction effect of cost control systems and information technology integration on manufacturing plant financial performance using a sample of 518 managers of U.S. manufacturing plants. According to them, while information technology integration and cost control systems do not provide significant independent effects on plant financial performance, they do interact to positively impact manufacturing plant financial performance.

Daoud and Triki (2013:1) examined by using the data from 102 Tunisian firms adopting ERP systems, that the accounting techniques used after ERP system adoption influence firm performance. They also found that the interaction effect of accounting staff competency with the AIS has a positive impact on firm performance improvement.

Suhaimi, Nawawı and Salın (2016: 93) examined the effectiveness of ERP system implementation on MCS and identify the changes in accountants' roles in the implementation of ERP systems. They found that ERP is an excellent device for a formal MCS, because of allowing companies to identify their wastage very early. In this way, ERP improved their work significantly as they can dedicate more time to financial analysis and decision making compared to data entry previously.

Quattrone and Hopper (2005: 735) analyzed the effects of ERP to MCS in two multinational organizations. They found that in one organization, the ERP reproduced existing structures and distance which permitted conventional accounting controls based on action at a distance to be maintained. The second organization used ERP to collapse distance through real-time information in a matrix structure. This did not increase centralization but rather produced constantly changing loci of control and managerial feelings of minimalist control.

Shaiti, (2014: 216-219) argues that the main purpose of firms adopting ERP is to control their internal transactions and processes. According to Shaiti, this requires an organizational cultural change. As a result of his observation, he suggests that in order to obtain effective ICPs, Saudi Arabian enterprises should take their organizational culture into consideration and direct it toward collaboration and coordination (though ERP systems). Morris (2011: 129) is also supports him by suggesting that ERP-implementing firms are less likely to report internal control weaknesses (ICW) than a matched control sample of non-ERP-implementing firms. $\mathrm{He}$ also found that this difference exists for both general (entity-wide), and individual (account-level) controls. Önce ve İşgüden (2012) have similar findings about the functionality of ERP for internal control units. According to the data from IMKB-100 firms, ERP supports positively to monitoring operations and processes and made all business processes automatically. Ramadhana, Govindaraju, and Wibisono (2016) point that technical and managerial support is important for ERP usage. They argue that ERP usage has a significant effect on dimensions of panoptic control. 
Ahlstrand and Selin (2011: 72-73) documented that ERP affects management control positively through five prime aspects; timeliness, accuracy, accessibility, richness, and control. ERP contribution as timeliness is also determined by kim, Nicolaou, and Vasarhelyi (2013: 63). According to Kim, ERP is negatively associated with the company's audit report lag and helps to reduce the delay in timely reporting.

Yu Ho (2006) and Yereli (2007:65) found that ERP has positive effects on planning, budgeting, reporting, analysis, and applications of advanced managerial accounting techniques. Spathis and Constantinides (2004:234) found that integration of applications, real-time information applications, and particularly information for decision-making are the underlying motives for Greek companies to adopt ERP systems. Their empirical evidence confirms that after the ERP implementation, a number of companies initiated the introduction of an internal audit function, the use of non-financial performance indicators, and profitability analysis at segmental/product level.

There are some studies on ERP functionality related with the business information system to better decision-making process. Galani, Gravas and Stavropoulos (2010: 774) find a greater level of information integration, flexibility in information access and greater functionality provided by ERP. On the other hand, Fahy and Lynch (1999: 5) found that while ERP improves the supply of transaction data for strategic management accounting activities, but can cause significant damage to existing decision support capability of the firm. However, the implementation of ERP leads to better information, more streamlined financial processes, better analysis and effective decision-making.

According to Granlund and Malmi (2002: 299), ERP has led to relatively small changes in management accounting and control procedures. The partial satisfaction caused by ERP is also emphasized by Booth, P., Matolcsy, Z., and Wieder B., (2000: 4). They found that ERP users are highly satisfied with reporting and decision support for finance and financial accounting, but they are less satisfied for transaction processing.

\section{Theoritical Framework and Hypothesis}

\subsection{ERP}

ERP can be identified as a complex computer-based information system including all business units and operation processes. According to some, ERP promise seamless integration of all information flows within and across organization and in principle allow any organizational object to be made visible (Dechow and Mouritsen, 2005: 692), are considered to be the most important development in corporate use of information technology (Jack ve Kholeif, 2008: 30), and is motivated by management's need for timely access to coherent information across the organisation units and functions (Shaiti, 2014: 40).

ERP is able to meet the different needs of different users, integrate all processes and functions of firms and give a holistic view to managers. Thanks to ERP, data on basic operational activities such as procurement, production, distribution, and sales are automatically recorded, and repetitions and errors in the data processing process are decreasing, resources in different geographical regions can be effectively controlled and coordinated, communication with customers and suppliers is improving, all personals can access information and reports instantly, and data updates are performed automatically. ERP supports the focus on strategic and operational issues that enable the development of the business process on the one hand while enabling routine accounting activities to be carried out more effectively (Granlund and Mouritsen, 2003: 82).

Shang and Seddon (2000: 1006) classified the benefits of ERP into five main headings. Cost reduction, cycle time reduction, productivity improvement, quality improvement, and customer service improvement are operational, better resource management, Improved decision-making and planning, and performance improvement are managerial, support to business growth and competitive advantage, configuring the innovation and regulation of external links are strategic, business flexibility, savings on info-tech cost, and strengthening of info-tech infrastructure are info-tech infrastructural, and support to organizational changes, organizational learning, empowerment, and built common visions are organizational benefits of ERP. 
Mahesha ve Akash (2013: 67) found that a number of accounting benefits (info-tech infrastructure, organizational, operational, managerial) derived from ERP systems particularly for accounting process. By evaluating ERP from an accounting perspective, Hyvonen, $T$ (2003: 155) and Scapens\&Jazayeri (2003: 201) found ERP eliminated the routine management accounting jobs, revealed line managers with accounting knowledge, provided more forward-looking information and a wider role for the management accountants.

\subsection{Management Control Systems (MCS)}

MCS is a very broad concept that includes many elements and used for various purposes. So, many authorities identify this concept according to own perspective. For Horngren, Foster and Datar (2000: 788), MCS is a means gathering and using the information to aid and coordinate the process of making planning and control decisions throughout an organization and to guide the behavior of its managers and employees. For Kloot (1997: 51), MCS "assist managers in performing all of the control functions of planning, decisionmaking, motivating, coordinating, communicating objectives, providing feedback and integrating activities within complex organizations, indicating the broad nature of control, not limited to accounting and budgeting systems. In short, MCS is the process of identification, measurement, accumulation, analysis, preparation, interpretation, and communication of information (Horngren, Sundem ve Stratton, 2004: 2) that assists executives to motivate employees to make decisions and to take actions which are in the organization's best interest (Malmi and Brown, 2008: 290).

Control may be in various forms. Formal and informal controls (Anthony, Dearden and Bedford, 1989), results, action and personnel controls (Merchant, 1985), diagnostic and interactive controls (simons, 2000:208), administrative and social controls (Hopwood, 1976), market, bureaucratic and clan controls (Ouchi, 1980: 130), planning, cybernetic, reward and compensation, administrative and cultural controls (Malmi and Brown, 2008: 291). The current trend in management control, as used our paper, is to combine the use of formal with informal systems, to create a control package.

Formal control system identified by written rules, standardized information-based procedures and routines is traditional feedback and measurement system. This system is used to monitor organizational outcomes, correct deviations from preset standards and reward behavior of employees for achieving the firm's goals. In this context, tracking potential problems and difficulties, limiting staff's behavior and encouraging staff in line with organizational goals are the main characteristics of a formal control system. This system supports the periodic execution of the same routines with little if any changes (Davila, Foster, Li, (2009:323) and for this purpose, the monitored and collected information is used with the aim of reporting and explaining. Formal control enhances managerial decision-making, reduces decision errors, and coordinates resources and capacity utilization (O'Connor, Vera-Muñoz, and Chan 2011: 247-248).

Elements of a formal system include organizational goals, budgetary guidelines, reward criteria, performance appraisal standards, and codes of ethics (Falkenberg and Herremans, 1995: 134). This makes managers effective to monitor resource allocation, to review past assessments, to transfer and to implicate current strategy to all personnel. In the frame of formal control, to motivate, to influence and to align all personnel with general organizational objectives is easier. The basic difficulty of formal control is that it does not give any signal if there is no deviation. Especially in a dynamic environment, this control type can be restrictive for such abilities creativity, gaining experience and improvement.

The Informal control system is not based on written rules to direct behavior. This system consists of common values, beliefs, attitudes, and traditions that promote goal congruence of organization members (Falkenberg and Herremans, 1995: 134), entails social interaction processes that focus on getting individuals to accept collective norms, values and goals as their own (Mahama, 2006: 320), supports the emergence of communication processes and mutual adjustment of organizational actors (Henri, 2006: 533), thus ensures working to reach these goals.

Informal control system aims to create an environment to maximize operational effectiveness, encourage organizational learning, focus attention on constantly changing information, encourage continual dialogue and debate unlimited creativity and involve employees and train staff to be self-monitoring, self- 
restraint and learned corporate values. Self-regulation, self-control, group control, and informal feedback are unspecific and unmeasurable basic mechanism of informal control system. In this way, informal control system is based on social and people-related strategies (Grabski and Leech, 2007: 20).

In the frame of the informal control system, accounting information system can create greater autonomy and accountability for subordinate managers and encourage them to discuss all problems and solutions (Kober, $\mathrm{Ng}$, and Byron, 2007:428). Interactive relationships between managers, taking control of the entire business process and determining and managing all strategic uncertainties are positive contributions for management process. Thus, firms can take advantage of opportunities, because of keeping organizational learning processes alive and making readiness for possible change.

\subsection{ERP-MCS Relationship}

According to general opinion, ERP affects MCS positively. Especially financial and non-financial information and eliminating barriers between entity's value chains located within and across organization give managers opportunities to manage everything with real-time information (Dorantes, Li, Peters and Richardson, 2013: 1430). ERP is expected to automate formal MCS tasks and provide opportunities for informal-based MCS. Supported MCS with ERP improve management's strategic analysis, operational-level analysis, and decision-making (Elbashir, Collier and Sutton, 2011: 158) also Dechow and Mouritsen (2005:725) Naturally, this improvement of managerial functions affects positively accounting functions and different parts of organizations.

The positive effect of ERP on MCS is examined in five sections. These are timeliness, accuracy, accessibility, richness, and control. Timeliness is very important for MCS, ERP has the positive contribution to MCS because of making information flow faster and timeliner and eliminating common bottlenecks. Secondly, ERP provides accurate and instant information to eliminate possible duty errors for MCS. Thirdly ERP makes a difference in information storing and presenting, thus all personnel are able to access this advanced information system continuously. ERP allows all personnel to enter rich information area. Thus, deeper and better cost-analysis based-MCS is possible, because of opportunities for all personnel to reach detailed and healthy information. Finally, MCS and observation all activities in a firm is easier with automated information process and accessibility to the inclusive information system.

The figure 1 shows the theoretical model of ERP-MCS interaction effect on firm performance.

Figure 1. Theoritical Model

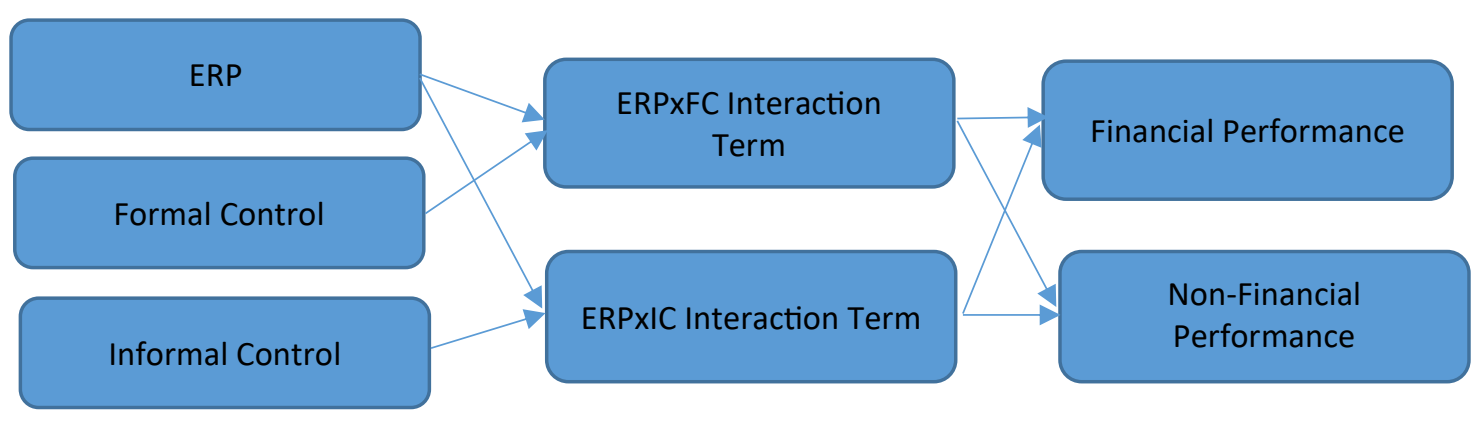

Type of control affects the way of ERP support to MCS. In a formal control system, ERP support management system based on standardization, rigid planning, feedback processes, integrate processes, more transparency, and comparable information. ERP provides information just what formal system needed comprehensive, healthy, timely and useful to firm-wide financial control documentation, automatically monitor workflow status and compliance processes in real time and to maintain information and security integrity which support the role of internal control monitoring objectives (Masli, Peters, Richardson, and Sanchez, 2010: 1004). With this kind of information, control operations turn to dynamic and iterative processes to monitor and to improve formal control activities (Turner and Owhoso, 2009:42). 
The main difference of ERP than traditional information system is speed. ERP is better to evaluate and report all opportunities and risks. Thanks to instant, comprehensive and healthy information, to encourage organizational discipline, to track operations regularly by users and to correct possible deviation immediately, are realized. In this frame, ERP contributes to formal control system on critical issues such as monitoring the instantaneous productivity and deviations by business employees, encouraging cost reduction and control, defining transactions and activities that do not create value, improving managerial decision making, reducing decision errors and coordinating resource and capacity using (O'Connor, Vera-Muñoz, and Chan, 2011: 247). Combined use of ERP and formal control system promise to solve the most urgent management problems, to mold the organization into the desired form, and, as a result, achieve a high level of performance (Teittinen, Pellinen and Järvenpää et.al, , 2013: 280).

ERP is also compatible with an informal control system. More transparency, increasing visibility of broad scope data, reinforcing and facilitating the teamwork and cross-functional integration required for the management of business processes are the functions provided by ERP to informal control system (Scapens and Jazayeri, 2003: 226-227). As known, in today's competitive environment, information sharing is very important for companies to identify problems, to develop solutions for them instantly, to evaluate the effect of the decisions taken at the institutional scale, and to reveal opportunities and threats. In this environment, as a result of combined used of ERP and informal control system, problems in operational processes are detected immediately, productive discussion and information platform for the resolution of these problems, a series of messages about issues such as problems they will focus on and problems they will investigate, methods expected to be used in their solutions, organizational values, basic success factors are delivered effectively and instantly to all personnel and thus organizational learning and value creation capacity are increasing.

ERP provides real-time data with fine granularity for informal control. This make managers enable to track and to view personnel performance. In addition, ERP data platform is based on mutual information sharing, so visibility and interdependency between workers and their peers is increased. In this regard, data errors, inconsistencies or lack of certain data can be seen and reported by others (Sehgal and Stewart, 2004).

ERP-informal control system integration provides a management structure that facilitates operational coordination between departments, strategic planning and management control can be done effectively through reachable financial and operational data by all units. Provided in this effective and mutual communication environment, all units are better able to understand each other's needs and solution proposals, harmonization of conflicting objectives is ensured, and accountability and autonomy of employees are increased and effective communication environment is created (Maas, Fenema ve Soeters, 2014: 91).

As customer and market are systematically monitored in ERP system, it is possible to obtain clear information about customers, markets, technologies, and competitors, respond more quickly to changes in the market, check whether current strategies are valid and if not, give all employees ideas about new strategic opportunities and procedures and thus the most rational strategic decisions can be made in a short time with the mutual interaction provided.

To summarize, the ERP system reduces the time and effort required to collect, analyze and report information for formal and informal control. In addition to this, accurate, comprehensive and instantaneous data contained in the system can be used, shared and even created by all employees.

The highly interactive use of ERP and MCS is expected to positively impact both financial and nonfinancial performance. For this reason, the following four research hypotheses are proposed.

H1: More extensive use of ERP-formal control interaction will have a positive direct effect on financial performance.

$\mathrm{H}$ 2: More extensive use of ERP-formal control interaction will have a positive direct effect on nonfinancial performance. 
H3: More extensive use of ERP-informal control interaction will have a positive direct effect on financial performance.

H4: More extensive use of ERP-informal control interaction will have a positive direct effect on nonfinancial performance.

\section{Methodology}

\subsection{The Nature of the Research and Sampling}

This study is based on data from 445 manufacturers located within the first 500 large enterprises in Turkey. The data forms for the study were mailed to top managers (general manager or vice general manager) of manufacturers included in the sampling on 01 September 2015. 125 questionnaires were returned and the turnover rate of the questionnaires was $31.1 \%$. The sectoral distributions of the manufacturers are presented in Table 1.

Table 1. Industry Distribution of Survey Respondents

\begin{tabular}{|l|r|r|r|r|}
\hline \multicolumn{1}{|c|}{ Industry } & Frequency & \multicolumn{1}{c|}{ Percent } & \multicolumn{1}{c|}{ Valid } & \multicolumn{1}{c|}{ Cumulative } \\
\hline Textile and clothing & 14 & 11,1 & 11,2 & 11,2 \\
\hline Food & 30 & 23,8 & 24,0 & 35,2 \\
\hline Construction & 8 & 6,3 & 6,4 & 41,6 \\
\hline Chemical and Petroleum & 9 & 7,1 & 7,2 & 48,8 \\
\hline Plastic & 9 & 7,1 & 7,2 & 56,0 \\
\hline Mining & 5 & 4,0 & 4,0 & 60,0 \\
\hline Metal wares and machine & 16 & 12,7 & 12,8 & 72,8 \\
\hline Wood and paper & 4 & 3,2 & 3,2 & 76,0 \\
\hline Automotive and spare parts & 16 & 12,7 & 12,8 & 88,8 \\
\hline Glass & 1 &, 8 &, 8 & 89,6 \\
\hline Electronic & 12 & 9,5 & 9,6 & 99,2 \\
\hline Alcohol and Tobacco & 1 &, 8 &, 8 & 100,0 \\
\hline Total & 125 & 99,2 & 100,0 & \\
\hline
\end{tabular}

Looking at the table, the sectoral distribution was realized as food and beverage sector by $24 \%$, metal products and automotive sector by $12.8 \%$, textile, clothing and footwear sector by $11.2 \%$ and electronics sector by $9.6 \%$ respectively.

\subsection{Data Collection Tool}

The questionnaire developed for the collection of research data consists of three parts. In the first part, we tried to find answers to four basic questions about ERP. It was aimed to determine whether surveyed enterprises use the ERP system, how long they use it, what ERP system applications they use, and finally what kind of benefits they have observed in accounting processes and processes in ERP implementation. The scale developed by Kanellou and Spathis (2013) was used to determine the benefits obtained in ERP implementation. Participants were asked to indicate in what dimensions they were monitoring the benefits of each item within the context of each item. For this; 5 likert scale was used, "never", "low", "medium", "high" and "very high".

In the second part, it was aimed to determine the level of application of formal and informal control system and the scale developed by Kallunki, Laitinen and Silvola (2011) was used in this frame. Participants are asked to indicate whether their firms use the items in the context of each item. For this; 5 likert scale was used, "never", "rarely", "sometimes", "usually", "always". 
In the last part, participants were asked to indicate their performance levels when compared to the sector average. In this framework participants were asked to express their views through the options "under the middle", "middle", "above the middle", from 1 (very low) to 9 (very high).

\subsection{Data Analysis}

In the study, the data obtained were entered into Pasw 18 statistical package program and multiple correlations analysis, multiple regression analysis and t-test analysis were used in the analysis of the data.

\subsubsection{Descriptive Statistics on ERP System}

Descriptive statistical data on the ERP of the participating firms are presented in the table below.

Table 2. Descriptive Statistics on ERP System

\begin{tabular}{|c|c|c|c|c|c|}
\hline & Frequency & $\begin{array}{c}\text { Current } \\
\text { Percentage }\end{array}$ & & Frequency & $\begin{array}{c}\text { Valid } \\
\text { Percentage }\end{array}$ \\
\hline ERP System Usage & & & ERP $\quad$ System & & \\
\hline - Yes & 96 & 76,2 & Applications & & \\
\hline - No & 26 & 20,6 & SAP & 45 & 45 \\
\hline - $\quad$ system started & 4 & 3,2 & Oracle & 7 & 7 \\
\hline to install & & & Baan & 3 & 3 \\
\hline Total & 126 & 100,0 & Microsoft Axapta & 12 & 12 \\
\hline ERP Usage Time & & & IFS & 8 & 8 \\
\hline 0-1 year & 2 & 2,0 & Netsis & 5 & 5 \\
\hline $1-2$ year & 2 & 2,0 & Likom & 3 & 3 \\
\hline 2-3 year & 7 & 7,1 & Others & 17 & 17 \\
\hline 3-4 year & 6 & 6,1 & Total & 100 & 100 \\
\hline 4-5 year & 16 & 16,2 & & & \\
\hline 5-10 year & 47 & 47,5 & & & \\
\hline 10-20 year & 19 & 19,2 & & & \\
\hline Total & 99 & 100,0 & & & \\
\hline
\end{tabular}

When the level of ERP usage of the participating enterprises is examined, it is seen that $76.2 \%$ (96) of the firms use the ERP system, $20.6 \%$ of the firms do not use the ERP system and $3.2 \%$ of the firms start to work on the ERP system. when looking at the ERP use period of the participating firms, $47.5 \%$ (47) of the firms are between 5 and 10 years, 19.2\% (19) of firms are between 10 and 20 years, $16.2 \%$ (16) of firms are between 4 and 5 years used ERP system. In addition to these, $45 \%$ of companies use SAP, $12 \%$ of companies use Microsoft Axapta, and $8 \%$ of companies use IFS ERP system.

\subsubsection{Factor Analysis}

The factor analysis was used to determine the factors that determine the benefits of the ERP system to accounting processes. In the analysis performed, the KMO measure of sampling adequacy was 0,862 . Factor analysis of these items was performed using basic component analysis and the "varimax" rotation technique. When the results of the factor analysis are examined, it can be seen that factor loadings of "improved quality of the reports- statements of account ", "improved internal audit function", "improved decisions based on timely and reliable information", "the accounting department communicates easier with other departments within the organization" and "increased flexibility in information generation" have almost equal loads in various factors. Thus, the analysis was carried out again by excluding these five variables.

At the end of the analysis, four factors were determined to have an eigenvalue greater than 1 . These factors explained $72.432 \%$ of the total variance. In the following rotated factor matrix, the first factor is called the IT accounting benefits, the second factor is the operational accounting benefits (time), the third factor is the managerial accounting benefits, and the fourth factor is the operational accounting benefits (time-cost). The 
results of factor analysis are presented in Table 3. The cronbach's alpha coefficients of the ERP system accounting utility were found to be $91.4 \%, 91.5 \%$ and $72.6 \%$, respectively, which indicated that there is good internal consistency of the survey data. However, the cronbach alpha coefficient of the operational accounting process (time-cost) was found to be $42.7 \%$, indicating that the internal consistency of the survey data is low.

Table 3. Benefits of the ERP System to Accounting Processes

\begin{tabular}{|l|r|r|r|}
\hline & $\begin{array}{l}\text { Factor } \\
\text { Loads }\end{array}$ & Medium & $\begin{array}{r}\text { Standard } \\
\text { deviation }\end{array}$ \\
\hline $\begin{array}{l}\text { Factor 1. Information technology (IT) accounting process } \\
\text { benefits }\end{array}$ & & $\mathbf{3 , 9 9 4 5}$ & $\mathbf{, 6 9 4 5 8}$ \\
\hline ERP produces results more quickly &, 845 & 3,9794 &, 81623 \\
\hline ERP produces results easier &, 827 & 3,9583 &, 79361 \\
\hline ERP gathers data easier &, 807 & 4,0619 &, 77479 \\
\hline ERP is user friendly &, 801 & 3,9479 &, 88698 \\
\hline ERP gathers data more quickly &, 746 & 4,1856 &, 76825 \\
\hline Reduction of time for transaction entry &, 716 & 3,8437 &, 93277 \\
\hline Factor 2. Operational accounting process benefits (time) & & $\mathbf{4 , 1 6 9 1}$ &, $\mathbf{6 8 2 9 2}$ \\
\hline Reduction of time for closure monthly accounts &, 898 & 4,2268 &, 77062 \\
\hline Reduction of time for closure annual accounts &, 896 & 4,1562 &, 79905 \\
\hline Reduction of time for closure quarterly accounts &, 874 & 4,2211 &, 74632 \\
\hline Increased integration of accounting applications &, 721 & 4,2268 &, 75698 \\
\hline Reduction of time for issuing financial statements &, 689 & 4,0206 &, 86578 \\
\hline Factor 3. managerial accounting process benefits & & $\mathbf{3 , 4 5 7 0}$ &, $\mathbf{8 8 7 5 7}$ \\
\hline Improved working capital control &, 845 & 3,4211 & 1,05769 \\
\hline Increased use of financial ratio analysis &, 770 & 3,5625 & 1,04441 \\
\hline ERP is more flexible in general &, 565 & 3,4124 & 1,17927 \\
\hline Factor 4. Operational accounting process benefits (time-cost) & & $\mathbf{3 , 4 0 7 2}$ &, $\mathbf{9 4 1 8 8}$ \\
\hline Reduction of time for issuing payroll &, 840 & 3,7083 & 1,29710 \\
\hline Reduction of personnel of accounting departmentı &, 584 & 3,0833 & 1,03280 \\
\hline
\end{tabular}

Taken in general to Table 3, it is possible to say that the benefits of the ERP system's accounting processes are above average. If the table is analyzed in detail, it will be seen that the meanings in the IT accounting process are 3,9945 and the meanings in the operational accounting process (time) are at a "high" level of 4,1691. This suggests that ERP has made a positive contribution to the accounting processes. In addition, It is seen that the mean values in the managerial accounting process are 3,4570 and the mean values in the operational accounting process (time-cost) are 3,4072. Accordingly, ERP contributes at the "middle" level.

The formal control system (FC) in the second part of the questionnaire consists of 10 items. Factor analysis of these items was performed using basic component analysis and the "none" rotation technique. The obtained factor analysis results were examined, "statistical quality control of production " and " systematic evaluation of managerial and senior staff personnel " variables with similar covariance were removed from the analysis of variance, and factor analysis was performed again. In repeated factor analysis, the KMO measure of sampling adequacy was 0.855 . At the end of the analysis, one factor was determined to have an eigenvalue greater than 1 . This factor explained $57.771 \%$ of the total variance. The results of factor analysis are shown in table 4. The Cronbach's alpha coefficient of formal control was found to be $89.5 \%$, which indicated that there is good internal consistency of the survey data. An overall measure of formal control was constructed by averaging the responses of the eight individual items. 
Table 4. Factor Analysis of Formal Control

\begin{tabular}{|l|c|}
\hline & Factor Loads \\
\hline Standard costs and the analysis of cost variances. &, 726 \\
\hline Marginal or incremental costing in "make or by" or pricing decisions. &, 675 \\
\hline Internal auditing. &, 791 \\
\hline Performance or operational auditing by outside auditors. &, 718 \\
\hline Use of internal rate of return/present value in evaluating investments. &, 800 \\
\hline Inventory control and production scheduling by means of operations research techniques. &, 797 \\
\hline Flexible or activity level budgeting. &, 812 \\
\hline Activity based costing. &, 750 \\
\hline
\end{tabular}

The informal control system (IC) in the second part of the questionnaire consists of 10 items. A factor analysis of the ten items was performed using a principal component analysis, and "none" was the rotation technique. In the factor analysis, the KMO measure of sampling adequacy was 0.911 . At the end of the analysis, one factor was determined to have an eigenvalue greater than 1 . This factor explained $57.888 \%$ of the total variance. The results of the analysis are given in table 5. The Cronbach's alpha coefficient of informal control was found to be $91.5 \%$, which indicated that there is good internal consistency of the survey data. An overall measure of informal control was constructed by averaging the responses of the ten individual items.

Table 5. Factor Analysis of Informal Control

\begin{tabular}{|l|c|}
\hline & Factor Loads \\
\hline An emphasis on consensus-seeking, staff participative decision making. &, 779 \\
\hline An emphasis on adaptation without concern for past practice. &, 813 \\
\hline Open channels of communication and free flow of information. &, 841 \\
\hline $\begin{array}{l}\text { An emphasis on initiative, and adaptation to the local situation rather than specialization } \\
\text { and top level co-ordination. }\end{array}$ &, 701 \\
\hline Easy informal access to senior managers. &, 422 \\
\hline $\begin{array}{l}\text { Managers encouraged to develop new ideas even if they fall outside the individual's area } \\
\text { of responsibility. }\end{array}$ &, 815 \\
\hline Tolerance of manager's mistakes, learning and sharing lessons learnt from them. &, 791 \\
\hline Managers share information with colleagues. &, 760 \\
\hline Fast reaction to take advantage of unexpected opportunities. &, 735 \\
\hline Current corporate culture encourages informal signaling of potential problem. &, 859 \\
\hline
\end{tabular}

Table 6. Factor Analysis of Firm Performance

\begin{tabular}{|l|r|r|r|}
\hline & \multicolumn{1}{|c|}{ 1.Factor } & 2.Factor & 3.Factor \\
\hline Non-Financial Performance & & & \\
\hline Human Resource Development &, 878 & & \\
\hline Employee Satisfaction &, 802 & & \\
\hline Customer Satisfaction &, 663 & & \\
\hline New Product Development level &, 660 & & \\
\hline Financial Performance-I & & & \\
\hline Return on Investment & &, 890 & \\
\hline Return on Assets & &, 823 & \\
\hline Operating Profits & &, 744 & \\
\hline Financial Performance-II & & &, 709 \\
\hline Sales Growth rate & & &, 707 \\
\hline Growth in the market & & &, 686 \\
\hline Cost of Sales Ratio & & &, \\
\hline Cash flow from operating activities & & & \\
\hline
\end{tabular}


Firm performance consists of twelve items. A factor analysis of the twelve items was used principal component analysis and "varimax" as rotation technique. The obtained factor analysis results were examined, market share variables (0.441) that have low covariance removed from the analysis of variance, factor analysis was performed again. In repeated factor analysis, the KMO measure of sampling adequacy was 0.832 . At the end of the analysis, three factors have been determined to have an eigenvalue above 1. Three factors explained $69.252 \%$ of the total variance. Cronbach's alpha coefficients of performance measures respectively, was found to be $81.3 \%, 90.3 \%$ and $73.1 \%$, which indicate very high internal reliability for the scale. An overall measure of financial I, financial II and non-financail performance was constructed by averaging the responses of the individual items.

\subsubsection{Descriptive Statistics and Correlation Analysis for All Variables}

In Table 7, descriptive statistical data on ERP, formal control (FC), informal control (IC), financial performance (FP) and non-financial performance (NFP) of the surveyed firms are presented.

Table 7. Descriptive Statistics for All Variables

\begin{tabular}{|l|l|l|l|l|c|}
\hline \multicolumn{1}{|c|}{ Variables } & NN & \multicolumn{1}{c|}{ Min. } & Max. & Mean & $\begin{array}{c}\text { Std. } \\
\text { Deviation }\end{array}$ \\
\hline ERP & 26 & 1,00 & 3,00 & 1,2698 &, 51245 \\
\hline Formal control & 15 & 1,00 & 5,00 & 3,8301 &, 96438 \\
\hline Informal control & 19 & 1,00 & 5,00 & 3,6820 &, 74675 \\
\hline Financial Perf.-I & 20 & 1,67 & 9,00 & 6,2417 & 1,62911 \\
\hline Financial Perf.-II & 21 & 3,00 & 9,00 & 6,4008 & 1,20825 \\
\hline Non-Financial Perf. & 21 & 2,00 & 9,00 & 6,5820 & 1,43210 \\
\hline
\end{tabular}

According to Table 7, the level of use of the formal control system varies between 1 and 5, the average is 3,8301. Firms participating in the survey; $43.5 \%$ (50) have always used the formal control system, $38.3 \%$ (44) usually use it and $12.2 \%$ (14) sometimes use it. Informal control system scores range from 1 to 5 , and the average is 3.6820. Firms that support the survey indicated that \%11.8 (14) have sometimes used informal control system, \%49.6 (59) usually use it and \%36.8 always use it. When looking at firm performance, financial performance-I values ranged from 1.67 to 9 and the average was 6.2417 . The financial performance-Il values ranged from 3 to 9 and the average was 6.4008. Finally, non-financial performance scores ranged from 2 to 9 and the average was 6.5820. The performance data obtained shows that the performance of firms is above average.

Table 8. Correlation Analysis for All Variables

\begin{tabular}{|l|c|c|c|c|c|c|c|c|}
\hline Variables & ERP & FC & IC & ERPXFC & ERPXIC & FP-I & FP-II & NFP \\
\hline ERP & 1 &, $190^{*}$ &,- 072 &, $748^{* *}$ &, $748^{* *}$ &, $181^{*}$ &,- 083 & 0.20 \\
\hline FC &, $190^{*}$ & 1 &, $683^{* *}$ &, $765^{* *}$ &, $541^{* *}$ &, $426^{* *}$ &, $364^{* *}$ &, $511^{* *}$ \\
\hline IC &,- 072 &, $683^{* *}$ & 1 &, $430^{* *}$ &, $588^{* *}$ &, $227^{*}$ &, $282^{* *}$ &, $492^{* *}$ \\
\hline ERPXFC &, $748^{* *}$ &, $765^{* *}$ &, $430^{* *}$ & 1 &, $847^{* *}$ & $360^{* *}$ &, 176 &, $375^{* *}$ \\
\hline ERPXIC &, $748^{* *}$ &, $541^{* *}$ &, $588^{* *}$ &, $847^{* *}$ & 1 &, $213^{*}$ &, 110 &, $274^{* *}$ \\
\hline FP-I &, $181^{*}$ &, $426^{* *}$ &, $227^{*}$ &, $360^{* *}$ &, $213^{*}$ & 1 &, $578^{* *}$ &, $572^{* *}$ \\
\hline FP-II &,- 083 &, $364^{* *}$ &, $282^{* *}$ &, 176 &, 110 &, $578^{* *}$ & 1 &, $512^{* *}$ \\
\hline NFP &, 020 &, $511^{* *}$ &, $492^{* *}$ &, $375^{* *}$ &, $274^{* *}$ &, $572^{* *}$ &, $512^{* *}$ & 1 \\
\hline
\end{tabular}

$* * 1 \%$ level of significance $* 5 \%$ level of significance

Table 8 presents the correlations between ERP, formal control, informal control and interaction terms with the performance levels of firms participating in the survey. According to this outcome, financial firm performance is positively and significantly correlated with all variables, and relations degree realized is in the order $0.181(p<0.05), 0.426(p<0.01), 0.227(p<0.05), 0.360(p<0.01)$ and $0.213(p<0.05)$. Again, according to the table, the correlation between financial performance-Il and formal and informal control was positive and the correlation was $0.364(p<0.01)$ and $0.282(p<0.01)$ respectively. However, no significant 
relationship between ERP-formal control interaction term and financial performance-II has been found. Table 8 shows that the correlation between non-financial performance variable and formal control, informal control, ERP-formal control interaction term, and ERP-informal control interaction term are in a positive direction and the relations degree realized is in the order $0.511(p<0.01), 0.492(p<0.01), 0.375(p<0.01)$ and $0.274(p<0.01)$.

\subsubsection{Multiple Regression Analysis}

To test the effect of ERP, formal control, informal control and interaction terms on the performance of the firm, the following multiple regression models were developed. In the first model, the effect of ERP, formal control, informal control on financial and non-financial firm performance was examined. In the second model, the effect of the ERP-formal control interaction term and the ERP-informal control interaction term on financial and non-financial firm performance is examined.

$\mathrm{Y}_{1}=\mathrm{b}_{0}+\mathrm{b}_{1} \mathrm{X}_{1}+\mathrm{b}_{2} \mathrm{X}_{2}+\mathrm{b}_{3} \mathrm{X}_{3}+e^{1}$

$Y_{2}=b_{0}+b_{1} X_{1}+b_{2} X_{2}+e^{2}$

Table 9. Financial Performance-I (Dependent Variable)

\begin{tabular}{|c|c|c|c|c|c|c|c|c|c|}
\hline Variables & $\begin{array}{l}\text { Non } \\
\text { Std. } \\
\text { Beta }\end{array}$ & $\begin{array}{l}\text { Std } \\
\text { Beta }\end{array}$ & $\begin{array}{c}\mathbf{t} \\
\text { Valuei }\end{array}$ & $\mathrm{P}$ & Variables & $\begin{array}{l}\text { Non } \\
\text { Std. } \\
\text { Beta }\end{array}$ & $\begin{array}{l}\text { Std } \\
\text { Beta }\end{array}$ & $\stackrel{t}{\mathbf{t}}$ Valuei & P \\
\hline Con & 3,875 & & &, 00 & & 4,913 & & & , 000 \\
\hline FC &, 625 & ,386 & 4,307 & , 00 & ERPX FC & ,195 & ,293 & 3,153 & ,002 \\
\hline \multicolumn{5}{|c|}{$\begin{array}{l}\text { Independent Variables: ERP, Formal Control, } \\
\text { Informal Control. } \\
F=18.551 ; p=0.000 ; r=0.386 ; r^{2}=0.141 \text {, Durbin- } \\
\text { Watson: } 2,126 \text {. }\end{array}$} & \multicolumn{5}{|c|}{$\begin{array}{l}\text { Independent Variables: ERPXFC interaction term, } \\
\text { ERPXIC interaction term. } \\
\text { F=9.938; } p=.002 ; r=0.293 ; r^{2}=(7.7) \text {, Durbin-Watson: } \\
2.135 \text {. }\end{array}$} \\
\hline
\end{tabular}

When we look at the regression model 1 in Table 9, about $14.1 \%$ of the changes in the firm's financial performance-I are due to the variables we included in the model. When examining the individual effect of the independent variables in the model, it appears that the other parameters have no meaningful significance on their own, apart from formal control, in explaining the financial performance-I $(p<0,05)$. Accordingly, it has been found that the formal control variable affects the firm's financial performance-l in a positive way with a strong beta coefficient $\left(\beta_{2}=.495 ; t=6.836, p=.000\right)$.

According to the regression result in Model 2, there was a significant positive correlation between the financial performance-I and the ERP-formal control interaction term $(\beta 2=.495 ; t=6.836, p=.000)$, but no significant relationship was found between the ERP-informal control interaction term. The mentioned interaction explains $29.3 \%$ of the change in the financial performance-l of the firms.

Table 10. Financial Performance-II (Dependent Variable)

\begin{tabular}{|c|c|c|c|c|c|c|c|c|c|}
\hline Variables & $\begin{array}{l}\text { Non } \\
\text { Std. } \\
\text { Beta }\end{array}$ & $\begin{array}{l}\text { Std } \\
\text { Beta }\end{array}$ & $\begin{array}{c}\mathbf{t} \\
\text { Value }\end{array}$ & $P$ & Variables & $\begin{array}{l}\text { Non } \\
\text { Std. } \\
\text { Beta }\end{array}$ & $\begin{array}{l}\text { Std } \\
\text { Beta }\end{array}$ & $\begin{array}{c}\mathbf{t} \\
\text { Value }\end{array}$ & $P$ \\
\hline Constant & 4,310 & & 9,755 &, 00 & Constant & 5,491 & & 15,255 &, 000 \\
\hline FC & ,523 & 411 & 4,668 & , 00 & ERP $x F C$ & ,118 & ,226 & 2,404 & ,018 \\
\hline \multicolumn{5}{|c|}{$\begin{array}{l}\text { Independent Variables: ERP, Formal Control, } \\
\text { Informal Control. } \\
F=21.789 ; \quad p=0.000 ; \quad r=0.411 ; \quad r^{2}=0.161 \text {, Durbin- } \\
\text { Watson: } 1.800 \text {. }\end{array}$} & \multicolumn{5}{|c|}{$\begin{array}{l}\text { Independent Variables: ERPXFC interaction term, } \\
\text { ERPXIC interaction term. } \\
F=5.779 ; \quad p=.018 ; \quad r=0.226 ; \quad r^{2}=4.2 \text {, Durbin-Watson: } \\
1.677 \text {. }\end{array}$} \\
\hline
\end{tabular}


When we look at the regression model 1 in Table 10 , it is seen that about $16.1 \%$ of the firm's financial performance-Il variance is derived from the variables we included in the model. When the effect of the independent variables in the model was examined, a meaningful and positive relationship was found between financial performance-II and formal control $(\beta 2=.411 ; t=4.668, p=.000)$, but no significant relationship was found between ERP and informal control.

When Model 2 is examined, it is seen that about $4.2 \%$ of the changes in the financial performance-II of the firms are derived from the interaction terms included in the model. The standardized beta coefficient in Tabloda 9 points out that the ERP-formal control interaction term affects the firm's financial performanceII in a positive direction ( $\beta 2=.226 ; t=2.404, p=.018)$. However, there is no significant relationship between the financial performance-II and the ERP-informal control interaction term.

Table 11. Non- Financial Performance (Dependent Variable)

\begin{tabular}{|c|c|c|c|c|c|c|c|c|c|}
\hline Variables & $\begin{array}{l}\text { Non Std. } \\
\text { Beta }\end{array}$ & $\begin{array}{l}\text { Std } \\
\text { Beta }\end{array}$ & $\begin{array}{c}\mathbf{t} \\
\text { Value }\end{array}$ & $P$ & Variables & $\begin{array}{c}\text { Non Std. } \\
\text { Beta }\end{array}$ & $\begin{array}{l}\text { Std } \\
\text { Beta }\end{array}$ & $\begin{array}{c}\mathbf{t} \\
\text { Value }\end{array}$ & $P$ \\
\hline Constant & 2,923 & & ,155 & 000 & Constant & 4,922 & & 11,278 & ,000 \\
\hline IC & ,568 & 312 & ,808 & 006 & $E R P \times I C$ & ,245 & 348 & 3,845 & ,000 \\
\hline FC & ,400 & 276 & ,487 & 014 & & & & & \\
\hline \multicolumn{5}{|c|}{$\begin{array}{l}\text { Independent Variables: ERP, Formal Control, } \\
\text { Informal Control. } \\
F=35.561 ; p=.000 ; r=0.539 ; r^{2}=0.277 \text {, Durbin-Watson: } \\
2.089 \text {. }\end{array}$} & \multicolumn{5}{|c|}{$\begin{array}{l}\text { Independent Variables: ERPXFC interaction term, ERPXIC } \\
\text { interaction term. } \\
F=14.784 ; \quad p=.000 ; \quad r=0.348 ; r^{2}=0.113 \text {, Durbin-Watson: } \\
2.086 \text {. }\end{array}$} \\
\hline
\end{tabular}

As shown in Table 11, approximately $27.7 \%$ of possible variances in non-financial performance level can be explained by independent variables participating in model 1 . When the standardized beta value is examined, it is found that there is a linear and significant relationship between non-financial performance and formal control $(\beta 2=, 276 ; t=2.487, p=.014)$ and informal control $(\beta 3=, 312 ; t=2.808, p=.006)$.

$11.3 \%$ of the variance in the dependent variable originated from the interaction terms involved in model 2. If we look at the $t$ values to evaluate the effect of each independent variable on non-financial performance, it is seen that the ERP-informal control interaction term has individual significance in explaining the dependent variable. Besides, the beta values in the table show that the ERP-informal control interaction term affects the non-financial performance of the firm positively $\left(\beta_{2}=.348 ; t=3,845, p=.000\right)$.

In summary, in the framework of the proposed hypotheses, it has been determined that the formal control and ERP-formal control interaction term affects the financial performance of the firms positively. In addition, it is seen that there is a linear relationship between the non-financial performance of the firm and formal control, informal control and ERP-informal control interaction term.

\subsection{5. t-test Analysis}

In this section, we explore whether the level of use of ERP, formal control, informal control and interaction terms varies between low and high financial and non-financial firm performance. With this aim, t-test analysis was performed and results of the analysis were presented in Table 12.

As suggested in the hypothesis, the t-test in table 12 shows that firms with high financial performance-I are more likely to use ERP and formal control than low performers. Another remarkable point in the table is that the high interaction between ERP and formal control and the high interaction between ERP and informal control have a positive impact on the firm's financial performance-l. 
Table 12. t-test Analysis for Financial Performance-I

\begin{tabular}{|l|c|c|c|}
\hline \multicolumn{1}{|c|}{ Variables } & $\begin{array}{c}\text { Firms having low } \\
\text { Financial Performance-I }\end{array}$ & $\begin{array}{c}\text { Firms having high } \\
\text { Financial Performance-I }\end{array}$ & $\begin{array}{c}\mathrm{t} \text {-value } \\
(\mathrm{p}=.001)\end{array}$ \\
\hline ERP & $\begin{array}{c}1,6721(, 47333) \\
\mathrm{n}=61\end{array}$ & $\begin{array}{c}1,8305(, 37841) \\
\mathrm{n}=59\end{array}$ & .046 \\
\hline Formal Control & $\begin{array}{c}3,5486(1,10934) \\
\mathrm{n}=57\end{array}$ & $\begin{array}{c}4,0694(, 70096) \\
\mathrm{n}=55\end{array}$ & .004 \\
\hline Informal Control & $\begin{array}{c}3,5508(, 76573) \\
\mathrm{n}=59\end{array}$ & $\begin{array}{c}3,7711(, 70522) \\
\mathrm{n}=57\end{array}$ & .110 \\
\hline ERPXFC Interaction term & $\begin{array}{c}6,2002(2,54546) \\
\mathrm{n}=57\end{array}$ & $\begin{array}{c}7,5524(1,98467) \\
\mathrm{n}=55\end{array}$ & .002 \\
\hline ERPXIC Interaction term & $\begin{array}{c}5,9729(2,01065) \\
\mathrm{n}=59\end{array}$ & $\begin{array}{c}6,8545(1,87509) \\
\mathrm{n}=57\end{array}$ & .016 \\
\hline
\end{tabular}

Table 13. t-test Analysis for Financial Performance-II

\begin{tabular}{|c|c|c|c|}
\hline Variables & $\begin{array}{c}\text { Firms having low Financial } \\
\text { Performance-II }\end{array}$ & $\begin{array}{l}\text { Firms having high Financial } \\
\text { Performance-II }\end{array}$ & $\begin{array}{l}\text { t-Value } \\
(p=.001)\end{array}$ \\
\hline ERP & $\begin{array}{c}1,8333(, 37618) \\
N=54\end{array}$ & $\begin{array}{c}1,6866(, 46739) \\
N=67\end{array}$ & .064 \\
\hline Formal Control & $\begin{array}{c}3,5466(1,10205) \\
N=54\end{array}$ & $\begin{array}{c}4,0604(, 75022) \\
N=59\end{array}$ & .004 \\
\hline Informal Control & $\begin{array}{c}3,4679(, 76931) \\
N=53\end{array}$ & $\begin{array}{c}3,8321(, 68455) \\
N=64\end{array}$ & .008 \\
\hline ERPXFC Interaction term & $\begin{array}{c}6,6488(2,50991) \\
N=54\end{array}$ & $\begin{array}{c}7,1145(2,26089) \\
N=59\end{array}$ & .302 \\
\hline ERPXIC Interaction term & $\begin{array}{c}6,4113(2,02842) \\
N=53\end{array}$ & $\begin{array}{c}6,4454(1,98269) \\
N=64\end{array}$ & .927 \\
\hline
\end{tabular}

Table 13 shows that firms with high financial performance-II used formal control and informal control to a greater extent than firms with low financial performance-II. In other words, t-test results indicate significant differences $(p<0.01)$ between groups in terms of formal and informal control. However, the twoway interaction between ERP and formal control showed no significant differences between firms with high and low financial performance-II.

Table 14. t-test Analysis for Non-Financial Performance

\begin{tabular}{|c|c|c|c|}
\hline Variables & $\begin{array}{l}\text { Firms having low Non- } \\
\text { Financial Performance }\end{array}$ & $\begin{array}{l}\text { Firms having high Non- } \\
\text { Financial Performance }\end{array}$ & $\begin{array}{c}\mathrm{t}-\text { Value } \\
(\mathrm{p}=.001)\end{array}$ \\
\hline ERP & $\begin{array}{c}1,7742(, 42153) \\
\mathrm{N}=62\end{array}$ & $\begin{array}{c}1,7288(, 44839) \\
N=59\end{array}$ & .567 \\
\hline Formal Control & $\begin{array}{c}3,4771(1,06659) \\
N=60\end{array}$ & $\begin{array}{c}4,1973(, 66129) \\
N=53\end{array}$ & .000 \\
\hline Informal Control & $\begin{array}{c}3,4186(, 75964) \\
N=59\end{array}$ & $\begin{array}{c}3,9199(, 63970) \\
N=58\end{array}$ & .000 \\
\hline ERPXFC Interaction term & $\begin{array}{c}6,4188(2,52698) \\
N=60\end{array}$ & $\begin{array}{c}7,4277(2,10801) \\
N=53\end{array}$ & .024 \\
\hline ERPXIC Interaction term & $\begin{array}{c}6,1508(1,94124) \\
N=59\end{array}$ & $\begin{array}{c}6,7139(2,02529) \\
N=58\end{array}$ & 127 \\
\hline
\end{tabular}


The t-test presented above shows that firms with high non-financial performance prefer to use more of the formal control, informal control, and ERP-formal control interaction term than firms with low nonfinancial performance. However, the two-way interaction between ERP and informal control showed no significant differences between firms with high and low non-financial performance.

\section{Conclusion}

In this study, which is based on the data of 125 manufacturing enterprises from among the top 500 in Turkey, the relation between the financial and non-financial performance of the enterprise and the terms ERP, formal control, informal control, and interaction has been tried to be empirically put forward.

According to results, It is seen that $76.2 \%$ (96) of the firms use the ERP system, $20.6 \%$ of the firms do not use the ERP system and 3.2\% of the firms start to work on the ERP system. Firms' use of ERP is as follows: $47.5 \%$ (47) of the firms are between 5 and 10 years, 19.2\% (19) of firms are between 10 and 20 years, 16.2\% (16) of firms are between 4 and 5 years used ERP system. In addition to these, $45 \%$ of firms use SAP, $12 \%$ of firms use Microsoft Axapta, and $8 \%$ of firms use IFS ERP system.

In the analysis of the data, factor analysis, correlation analysis, multiple regression analysis and t-test analysis were used. When we look at the correlation table, the relationship between both financial and nonfinancial performance and formal control, informal control, ERP-formal control interaction term, ERPinformal control interaction term is meaningful and correlation is positive.

According to the results of regression analysis, there is a meaningful and positive relationship between financial performance and formal control and ERP-formal control interaction term, and it has also been found that there is a linear and meaningful relationship between non-financial performance and formal control, informal control, and ERP-informal control interaction term.

T-test analysis attempted to explain how ERP, formal control, informal control and interaction terms varied between high and low financial / non-financial performance levels with a view to making the relationship more clear. According to the analysis, firms with high financial performance use ERP, formal control, ERP-formal control interaction and ERP-informal control interaction more than low performance. Another remarkable point in the $t$ table is that firms with high non-financial performance use more of the formal control, informal control and ERP-formal control interaction terms from low performance firms. In contrast to the hypothesis, there is no significant difference between firms with high and low non-financial performance in terms of two-way interaction between ERP and informal control.

The selected sample is composed of senior managers of the first five hundred manufacturing firms in Turkey. Different studies can be done using more comprehensive and different samples related to the topic. It may be possible to develop new perspectives according to the results obtained. Again, the studies to be done by the use of different control typologies will contribute to the enrichment of the literature, allowing comparison with the results of this study.

\section{End Notes}

1. $Y 1=$ Firm Performance; $X_{1}=E R P, X_{2}$ : Formal Control, $X_{3}:$ informal Control, $e=$ Error term.

2. $Y 2=$ Firm Performance $X_{1}=E R P X F C$ interaction term, $X_{2}: E R P X I C$ interaction term, $e=$ Error term. 


\section{References}

Ahlstrand, T., \& Selin, J. (2011). What happens with control when fundamentals change? A study of how an ERP implementation may affect management control by causing changes among supporting roles and activities. Master Thesis Within Business Administration, Jönköping International Business School, Https://www.DivaPortal.Org/Smash/Get/Diva2:420120/FULLTEXT01.Pdf.

Anthony, R., Dearden, J., \& Bedford, N. M. (1989). Management control systems. 6th Edition, Homewood, III, Irwin.

Beaubien, L. (2013). Technology, change, and management control: A temporal perspective. Accounting, Auditing \& Accountability Journal, 26(1), 48-74.

Booth, P., Matolcsy, Z., \& Wieder B. (2000). The impacts of enterprise resource systems on accounting practice-The Australina experience. Australian Accounting Review, 10(3), 4-18.

Daoud, H., \& Triki, M. (2013). Accounting information systems in an ERP environment and Tunisian firm performance. The International Journal of Digital Accounting Research, 13, 1-35.

Davila, A., Foster, G., \& Li, M. (2009). Reasons for management control systems adoption: Insights from product development systems choice by early-stage entrepreneurial companies. Accounting, Organizations and Society, 34, 322-347.

Dechow, N., \& Mouritsen, J. (2005). Enterprise Resource Planning systems, management control and the quest for integration. Accounting, Organizations and Society, 30(78), 691-733.

Dechow, N., Granlund, M., \& Mouritsen, J. (2007). Management control of the complex organization : Relationships between management accounting and information technology. Handbook in Management Accounting Research. Ed./C. Chapman; A. Hopwood; M. Shields. Vol. 2 Amsterdam : Pergamon Press, 625-640.

Dorantes, C.A., Li, C., Peters, G.F., \& Richardson, V.J. (2013). The effect of enterprise systems implementation on the firm information environment. CAR, 30(4), 1427-1461.

Elbashir, M.Z., Collier, P.A., \& Sutton, S.G. (2011). The role of organizational absorptive capacity in strategic use of business intelligence to support integrated management control systems. The Accounting Review, 86(1), 155184.

Fahy, M.J., \& Lynch, R. (1999). Enterprise Resource Planning (ERP) systems and strategic management accounting. Paper Presented at The 22nd Annual Congress of The European Accounting Association, Bordeaux, May 5-7.

Falkenberg, L., \& Herremans, I. (1995). Ethical behaviours in organizations: Directed by the formal or informal systems? Journal of Business Ethics, 14(2), 133-143.

Galani, D. Gravas, E., \& Stavropoulos, A. (2010). The Impact of ERP systems on accounting processes. International Journal of Social, Behavioral, Educational, Economic, Business and Industrial Engineering, 4(6), 774-779.

Grabski, S.V., \& Leech, S.A. (2007). Complementary controls and ERP implementation success. International Journal of Accounting Information Systems, 8, 17-39.

Granlund, M., \& Malmi, T. (2002). Moderate impact of ERPS on management accounting: A lag or permanent outcome? Management Accounting Research, 13(3), 299-321.

Granlund, M., \& Mouritsen, J. (2003). Special section on management control and newinformation technologies. European Accounting Review, 12(1), 77-83.

Henri, J.F. (2006). Management control systems and strategy: A resource-based perspective. Accounting, Organizations and Society, 31, 529-558.

Hopwood, A.G. (1976). Accounting and Human Behavior. New Jersey: Prentice Hall.

Horngren, C.T., Sundem, G.L., \& Stratton, W.O. (2004). Introduction to management accounting. 13th Edition, New Jersey: Prentice Hall.

Horngren, C.T., Foster, G., \& Datar, S.M. (2000). Cost accounting a managerial emphasis. New Jersey: Prentice Hall.

Hyvonen, T. (2003). Management accounting and information systems: ERP versus Bob. European Accounting Review, 12(1), 155-173.

Jack, L., \& Kholeif, A. (2008). Enterprise resource planning and a contest to limit the role of management accountants: A strong structuration perspective. Accounting Forum, 32, 30-45.

Kallunki, J.P., Laitinen, E.K., \& Silvola, H. (2011). Impact of Enterprise Resource Planning systems on management control systems and firm performance. International Journal of Accounting Information Systems, 12, $20-39$. 
Kanellou, C. Spathis (2013). Accounting benefits and satisfaction in an ERP environment. International Journal of Accounting Information Systems, 14, 209-234.

Kim,J., Nicolaou, A.I., \& Vasarhelyi, M.A. (2013). The impact of Enterprise Resource Planning (ERP) systems on the audit report lag. Journal of Emerging Technologies in Accounting, 10(1), 63-88.

Kloot, L. (1997). Organizational learning and management control systems: Responding to environmental change. Management Accounting Research, 8(1), 47-73.

Kober, R., Ng, J., \& Paul, B.J. (2007). The interrelationship between management control mechanisms and strategy. Management Accounting Research, 18, 425-452.

Leslie D. Turner, L.D., \& Owhoso, V., (2009). Use ERP internal control exception reports to monitor and improve controls. Management Accounting Quarterly, 10(3), 41-50.

Maas, J.B., Fenema, P.C., \& Soeters, J. (2014). ERP system usage: The role of control and empowerment. New Technology, Work and Employment, 29(1), 88-103.

Mahama, H. (2006). Management control systems, cooperation and performance in strategic supply relationships: $A$ survey in the mines. Management Accounting Research, 17, 315-339.

Mahesha V., \& Akash, S.B. (2013). Management accounting benefits: ERP environment. SCMS Journal of Indian Management, July-September, 67-74.

Maiga, N., \& Jacobs, F. A. (2013). Assessing the interaction effect of cost control systems and information technology integration on manufacturing plant financial performance. The British Accounting Review, XXX, 1-14.

Malmi, T., \& Brown, D.A. (2008). Management control systems as a package--opportunities, challenges and research directions. Management Accounting Research, 19, 287-300.

Maroofi, F., Kiani, M.A., \& Nazaripour, M. (2012). Impact of Enterprise Resource Planning systems on company performance and management control systems. International Journal of Business Environment, 5(1), 51-73.

Masli, A., Peters, G.F., Richardson, V.J., \& Sanchez, J.M. (2010). examining the potential benefits of internal control monitoring technology. The Accounting Review, 85(3), 1001-1034.

Merchant, K. A. (1985). Controll in business organizations, Boston: Pitman.

Morris, J. (2011). The impact of Enterprise Resource Planning (ERP) systems on the effectiveness of internal controls over financial reporting. Journal of Information Systems, 25(1), 129-157.

O'Connor, N.G., Vera-Muñoz, S.C., \& Chan, F. (2011). Competitive forces and the importance of management control systems in emerging-economy firms: The moderating effect of international market orientation. Accounting, Organizations and Society, 36, 246-266.

Ouchi, W.G. (1980). Markets, bureaucracies, and clans. Administrative Science Quarterly, 25(1), 129-141

Önce, S., \& İşgüden, B. (2012). İç denetim faaliyetinin gelişen ve değişen bilgi teknolojileri ortamı açısından değerlendirilmesi: iMKB-100 örneği. Yönetim ve Ekonomi Araşttrmaları Dergisi, 17, Doi:Http://Dx.Doi.Org/10.11611/JMER3.

Quattrone, P., \& Hopper, T. (2005). A-time space odyssey: Management control systems in two multinational organisations. Accounting, Organizations and Society, 30, 735-764.

Ramadhana, B. A., Govindaraju, R., \& Wibisono, Y. Y. (2016). ERP system usage and panoptic control: The role of perceived organizational support. Proceedings of The 2016 IEEE IEEM.

Scapens, R.W., \& Jazayeri, M. (2003). ERP systems and management accounting change: Opportunities or impacts? A research note. European Accounting Review, 12(1), 201-233.

Sehgal, R., \& Stewart, G., (2004). Exploring the relationship between user empowerment and enterprise system success measures. In The AMCIS.

Shaiti, H.K. (2014). The relationship between ERP systems success and internal control procedures: A Saudi Arabian study. PHD Thesis, University Of Bedfordshire. Https://Core.Ac.Uk/Download/Pdf/77037989.Pdf.

Shang, S., \& Seddon, P.B. (2000). A comprehensive framework for classifying the benefits of ERP Systems. AMCIS 2000 Proceedings, 39, Http://Aisel.Aisnet.Org/Cgi/Viewcontent.Cgi ?Article=1452\&Context=Amcis2000.

Simons, R. (2000). Performance measurement \& control systems for implementing strategy. New Jersey: Prentice-Hall Inc.

Spathis, C., \& Constantinides, S., (2004). Enterprise Resource Planning systems' impact on accounting processes. Business Process Management Journal, 10(2), 234-247. 
The Impact of Interaction Between Enterprise Resource Planning System and Management Control System on Firm Performance in The Turkish Manufacturing Sector

Suhaimi, N.S.A., Nawawi, A., \& Salin, A.S.A.P. (2016). Impact of Enterprise Resource Planning on management control system and accountants' role. Int. Journal of Economics and Management, 10(1), 93 - 108.

Teittinen, H., Pellinen, J., \& Järvenpää, M. (2013). ERP in action- challenges and benefits for management control in SME context. International Journal of Accounting Information Systems, 14, 278-296.

Yereli, A.N., (2007). Yeni nesil Kurumsal Kaynak Planlaması Sistemi'nin yönetim muhasebesi açısından değerlendirilmesine yönelik bir araştirma. Yönetim ve Ekonomi Dergisi, 14(2), 65-80.

Yu Ho, T. (2006). Impact of ERP and OLAP systems on management accounting practices and managements accountants. Master's Thesis in Accounting, Swedish School Of Economics and Business Administration. 